the potentialities of such a hybrid system in power system applications.

Experimental work on the current-carrying capacity of cables continues in relation both to steady-state and to fault conditions, and considerable information has been obtained from the co-operative field investigation on the influences of the thermal properties of soil. In relation to the calculation of cable ratings, methods are being developed for the utilization of digital computer programmes.

The behaviour of the British electricity supply system in relation to thunderstorm activity throughout the ten-year period 1950-60 is the subject of a comprehensive report. 'The report examines the frequency of supply interruptions in the high-voltage system, their relationship with thunderstorm activity, the effect of arc suppression coils, the rate of equipment failure and the protective effects of surge diverters and spark gaps on the rate of transformer failures. Reports have also been issued analysing the frequency and distribution of thunderstorms in Britain for the years 1962 and 1963, and a ten-year thunderstorm map of Britain for the period 1955-64 is in preparation. The collection of statistical information on the frequency of lighting discharges in different parts of the world is being facilitated by the adoption, as an interim international standard, of a modification of a form of lightningflash counter originally developed in association with the Electrical Research Association.

Electric heating is represented, in the main, by a group of researches relating to off-peak floor heating, to ceiling heating and to thermal storage. The storage of off-peak energy by means of the lime-water reaction has been studied on a full-scale test equipment in the laboratory and, following a comprehensive theoretical assessment, experiments have been put in hand on the use of sodium hydroxide.

Within the division dealing with industrial applications, the programme of work on electrical equipment for hazardous atmospheres continues. In the same division research on methods of reducing contact erosion is being pursued by a detailed study of a novel dissimilar metal system.
It appears, from theoretical considerations, that metal transfer could be virtually eliminated for a certain range of eireuit conditions by the use of suitably chosen dissimilar contact metals. This has been confirmed in a series of experiments using platinum as the positive and silver or palladium as the negative electrode. Experimental work on unbalanced magnetic pull in electrical machines is now in progress on a machine specially constructed and instrumented for these measurements.

The major part of the programme of the Electronics Department is on thin films and is supported by a group of industrial contributors and by the Ministry of Aviation. It is reported that work on the deposition of metal from an ion beam has encountered difficulties, due to a flow of neutral gas molecules from the ionization chamber through the extractor electrode. The Penning ion source has been replaced by one utilizing electron bombardment to ionize copper vapour. Experimental capacitors have been made by depositing silicon oxide dielectric films on gold electrodes. Early results, however, suggest that the silicon oxide films deposited under ultra-high vacuum conditions may be insufficiently oxidized. Work on the conduction mechanism in thin films has led to an investigation of the influence of the substrate material. It has been shown that the electrical conductivity of glasses used as substrates for microcircuits is high enough to contribute to the transport of electric charges by a thin film deposited on the surface. Two new lines of investigation have been started, one on the properties of semi-conductor materials in thin film form and the other on the resistance changes occurring in thin gold films when subjected to mechanical strain.

Some of the fundamental theoretical work which has been done in applying the theory of the electrical discharge to certain astrophysical phenomena has undergone further comparison with observation. During the past year it has been demonstrated that the maximum magnetic fields recorded by Babcock's solar magnetograph of the order of 1,000 gauss are compatible with the much larger fields of $10^{4}-10^{5}$ gauss deduced from the theory of solar flares some years ago.

\title{
POWER SUPPLY IN BRITAIN
}

$\mathrm{N}$ asking the House of Commons on August 4 to note 1 the Report and Accounts of the Electricity Council for 1963-64 and of the Central Electricity Generating Board for 1963-64, Mr. F. Le日, the Minister of Power, said that the average cost of new conventional power stations had fallen from about $£ 60$ per $\mathrm{kW}$ in 1955 to about $£ 40$ to-day. Britain had by far the largest output from commercial nuclear power stations of any country, and was producing more nuclear power than the whole of the rest of the Western world, including the United States. Whatever the outcome of the Government's present review of the second nuclear power programme, the industry would continue to need coal for many years to come, and the Generating Board was now using 64 million tons of coal, compared with 61 million tons in 1963-64. Fifteen new coal-fired stations were under construction, partly to replace the older stations which were closing down, and on completion of these stations the Generating Board would have much of its capacity in the form of new coal-fired stations. The working life of the new stations would be twenty-five years or more, and they would burn coal with high efficiency in the 500-MW sets which had been adopted as standard for the next few years. Forty-seven of these sets were now on order and they would produce substantially more power than the entire capacity of the industry ten years ago.

On the transmission side, the industry was introducing transmission at $400 \mathrm{kV}$. Great efforts were being made at considerable cost to reduce the impact of the new lines on the countryside and this research had high priority. Some research was being undertaken into the use of d.c. transmission instead of a.c., and about one-third of the total expenditure of the Board on transmission lines in 1964 was spent on underground cables. This was expected to rise to more than two-thirds by 1970 , and during the three years, commencing in 1968, the Board expected to spend $£ 39$ million on 1,350 miles of overhead lines, and $£ 107$ million on 500 miles of underground cable. Rural electrification was now approaching completion, and 94 per cent of the 280,000 farms in England and Wales had an electricity supply. In distribution, as in generation and transmission, research was going ahead and a now laboratory had been set up at Capenhurst. The major effort at the new laboratory would be concentrated on research into distribution and on appliances and methods of using electricity as part of a research programme covering generation, transmission and distribution, on which the industry planned to spend $£ 10$ million this year.

The Minister's observations on research were generally welcomed in the debate, but Mr. A. F. Palmer suggested that there might have been some neglect of research into the use of direct current. Sir Richard Nugent pointed out that the Select Committee on the Nationalized Industries had been critical of expenditure on research on transmission, and especially on distribution, particularly 
by the area boards. Mr. J. H. Osborn suggested that the Ministry, the Central Electricity Generating Board, and the Atomic Energy Authority might survey the variety of pressurized water reactors, and asked whether the virtues of a boiling-water and similar types of reactor for smaller power stations were being considered. The achievement of the Atomic Energy Authority in developing the advanced gas reactor was welcomed in the debate. Mr. Osborn and also Mr. E. Lubbock and Mr. P. Jenkin were critical of its comparative cost compared with that of the boiling-water reactor developed in the United States at
Oyster Creek: this, it was said, could produce electricity at $0.34 d$. per unit. These and other speakers in the debate repeatedly stressed the importance of research. In replying on the debate, Mr. J. Morris, the Parliamentary Secretary to the Ministry of Power, said that the Minister was satisfied with the programmes to date and referred to the greater co-operation and co-ordination recently established between the gas, electricity and coal industries. As regards Oyster Creek, he said that this was not a comparison of like with like, and the Dungeness tenders were all competitive under British conditions.

\section{BRITISH RESEARCH AND DEVELOPMENT IN TECHNOLOGY}

$I_{M}^{\mathrm{N}}$ $\mathrm{N}$ a written answer in the House of Commons on July 27, Mr. F. Cousins, the Minister of Technology, said that the National Research Development Corporation was making available funds in support of programmes and projects of research and development by various firms in the computer industry. His Department would continue to support the industry by sharing the cost of contracts under the Advanced Computer Techniques Programme, involving additional commitments by the Government of about $£ 500,000$ in $1965-66$ and through contracts with universities for research in industry to a further $£ 500,000$. Arrangements had been made with the Minister of Housing and Local Government to bring the Computer Advisory Service to the notice of local authorities. Twenty-three British and six American computers were on order for Government departments, including the General Post Office; 12 computers of American design and foreign manufacture were in use in Government departments, and 58 in the nationalized industries. Eighty computers manufactured in Britain were in use in Government departments and 66 in the nationalized industries. A collaborative programme between the Atomic Energy Authority and industry on the desalination of sea-water was under way and a design study for a 30-Mgal./day plant, using flash distillation techniques, had been completed in conjunction with Weir, Westgarth, Ltd.

Mr. Cousins said that he had appointed Dr. J. B. Adams to be controller in the Ministry of Technology with effect from July 12, and that Dr. Adam would be in charge of all the scientific and technological work of the industry. An organization chart for the Ministry of Technology was published in the Official Report for July 27, and the responsibilities of the Economics and Statistics Division were listed in detail. This Division is organized in four branches: (1) Economics Branch, responsible for advising on the economics aspects of the Ministry's policies and programmes. This Branch provides support for the studies of industries conducted by the technological appraisal groups within the Ministry. (2) Statistics Branch, which is responsible for collating, analysing and interpreting statistics of industries for which the Ministry has sponsoring functions. These statistics are collected for the Ministry by the Board of Trade. (3) Manpower
Branch, which is concerned with manpower resources for science and technology and keeps under review the human and social problems resulting from technological change. (4) Engineering Branch, which has the main function of initiating or encouraging action to enhance the status of engineers and to improve the supply. It is also responsible for co-ordinating the implementation of the recommendations of the Fielden Report on Engineering Design.

$\mathrm{Mr}$. Cousins also stated that the Ministry communicated technological information by personal contact, scientific and technical publications, exhibitions, conferences, press, film, radio and television, and was building up a network of regional offices and industrial liaison centres to supplement this effort. The Ministry's laboratories dealt with about 2,500 enquiries each month, mainly from industry. Much information was being received from scientific counsellors in foreign countries. The Department was undertaking a technical and economic study of the scientific industrial process-control instrument industry, and had initiated studies of engineering standards, the metric system and the industrial use of new materials. Also contained in the Official Report for July 27 was a full list of the leaders of the various scientific and technological teams studying selected industries and processes, with their date of appointment and relevant experience.

On July 27, replying to a question regarding the Advisory Council on Technology in the House of Lords, Lord Snow, the Parliamentary Secretary to the Ministry, said that the Council had met ten times; its terms of reference were to advise on the application of advanced technology in British industry and to give special attention to the industries for which the Minister had sponsorship responsibility. Among subjects considered have been the status of engineers and designers, development of British standards for export markets, the promotion of the metric system and problems of industrial structure. The relations between the Council for Scientific Policy and the Advisory Council on Technology were close and there was common membership. Lord Snow thought that there was no danger of any serious lacuna between them. Relations between the Ministry and the Department of Economic Affairs must also be close and he thought there was little danger of overlapping.

\section{THE MELLON INSTITUTE}

$\mathrm{T}$ HE fifty-second annual report of the Mellon Institute * covers the year ended Fobruary 28, 1965, at the close of which the staff of 539 included 355 professional and technical members. A list of visitors' lectures at colloquia is appended, and another of members' publications during the year. The brief accounts of research investigations

* Mellon Institute. Fifty-second Annual Report for the Fiscal Year ended February 28, 1965. Pp. 40. (Pittsburgh: Mellon Institute, 1965.) during the year refer, under biochemistry and molecular biology, to improvements in instrument design and experimental procedures which have given a precision of $0 \cdot 2-0 \cdot 3$ per cent in determining sedimentation coefficients in examining structural transformations in Bromegrass mosaic virus, while further electron microscopical studies of actomyosin have confirmed the identification of 'ladders' as the principal morphological form of con- 